\title{
Sighting of Indian grey hornbill and Rufous woodpecker at Nandankanan Wildlife Sanctuary, Odisha, India
}

\section{Abstract}

Nandankanan Wildlife Sanctuary, Odisha, India is home to a rich assemblage of faunal and floral diversity including 121 species of bird species. The present communication reports addition of two new species namely Indian grey hornbill Ocyceros birostris (Scopoli, 1786) and Rufous woodpecker Micropternus brachyurus (Vieillot, 1818) to the existing checklist of Nandankanan Wildlife Sanctuary.
Volume 3 Issue 4 - 2018

\author{
Rajesh Kumar Mohapatra \\ Biologist, Nandankanan Zoological Park, Odisha, India
}

Correspondence: Rajesh Kumar Mohapatra, Nandankanan Zoological Park, Odisha, India, Tel +9199 3756 3742, Email rajesh.wildlife@gmail.com

Received: June 6, 2018 | Published: July 31, 2018

\section{Observations}

Nandankanan Wildlife Sanctuary (NWS) is located between $20^{\circ} 23^{\prime} 08^{\prime \prime}$ to $20^{\circ} 24^{\prime} 10^{\prime \prime} \mathrm{N}$ and $85^{\circ} 48^{\prime} 09^{\prime \prime}$ to $85^{\circ} 48^{\prime} 13^{\prime \prime}$ E, spreading over an area of 4.37 sq.km in the state of Odisha, Eastern India. The sanctuary enjoys a moderately hot humid climate around $30^{\circ} \mathrm{C}$ with annual average rainfall of $1350 \mathrm{~mm}$. The vegetation is of moist mixed deciduous type. ${ }^{1}$ There is scanty literature on birds of NWS. Kamal et al., ${ }^{2}$ recorded 53 species of birds from "Kanjia" lake of NWS. A checklist of 120 species of birds of 41 families was reported by Panda et al., ${ }^{3}$ Mohapatra et al. added one more species i.e., Stork billed kingfisher (Pelargopsis capensis) to the checklist. ${ }^{4}$ The present note intends to report addition of two new species to the above checklist. The sighted birds are Indian grey hornbill Ocyceros birostris (Scopoli, 1786) (Figure 1). Rufous woodpecker Micropternus brachyurus (Vieillot, 1818) (Figure 2). Both birds were sighted and photodocumented by the author during ad libitum field survey inside the sanctuary area. Both species were identified on site and confirmed. ${ }^{5,6}$ Indian Grey Hornbill is grey colored with white under parts, red iris $\&$ a tail with white tip and dark sub-terminal band. The bill is darkgrey to black surmounted with a casque extending upto the point of curvature in the bill. Rufous Woodpecker is a medium sized rufous colored bird with short black bill and black barring on the wing and tail. The bird lacks a crest. Male has crimson patch on ear covert which is pale buff in case of female. ., $^{5,}$

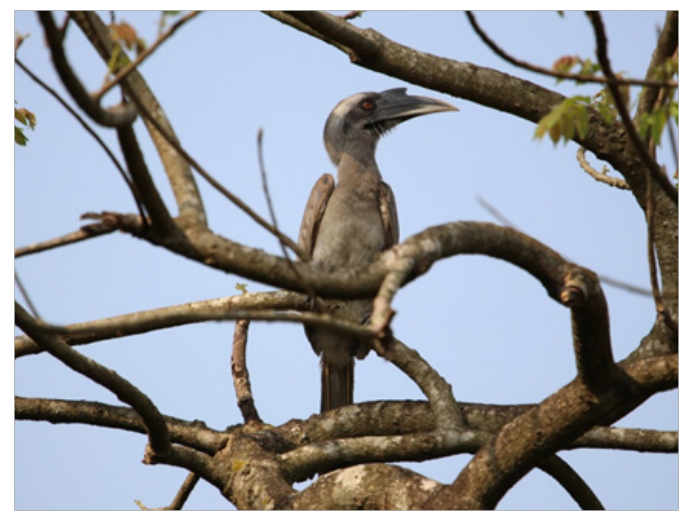

Figure I Indian grey hornbill Ocyceros birostris at NWS.

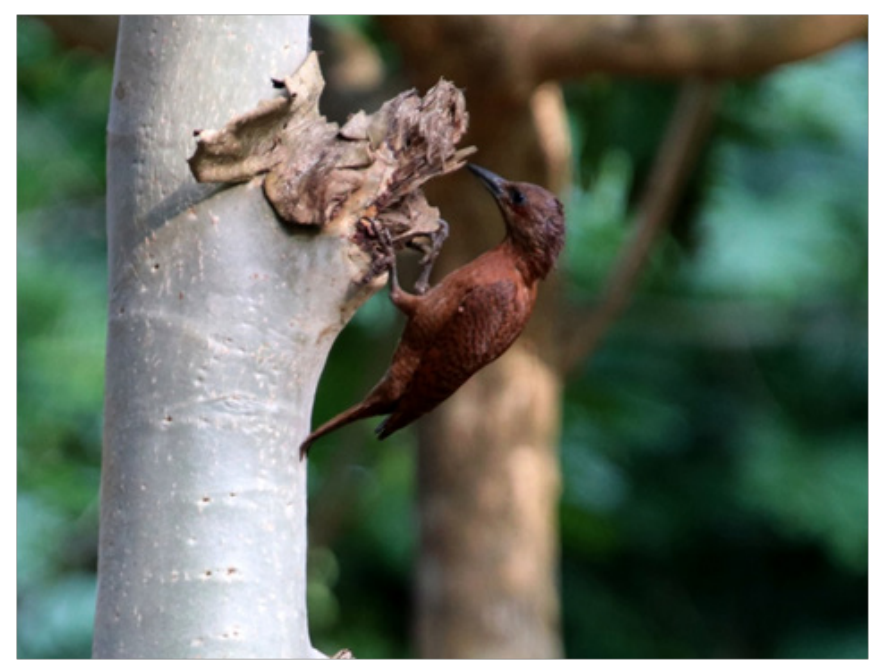

Figure 2 Rufous woodpecker Micropternus brachyurus at NWS.

Spatiotemporal details of sightings of Indian grey hornbill and Rufous woodpecker were given in the Table 1. Indian grey hornbill has a wide distribution range including India, Bangladesh, Pakistan and Nepal. ${ }^{7}$ In odisha the species was reported from Sundargarh, ${ }^{6,8}$ Ganjam, ${ }^{910}$ Athagarh, Cuttack, ${ }^{11}$ Joda, Keonjhar districts ${ }^{12}$ and Baisipalli Wildlife Sanctuary ${ }^{13}$ spreading over Nayagarh and Boudh districts of Odisha. Rufous woodpecker is having a very wide distribution range including India; Bangladesh; Bhutan; Brunei Darussalam; Cambodia; China; Indonesia; Lao People's Democratic Republic; Malaysia; Myanmar; Nepal; Singapore; Sri Lanka; Thailand; Viet Nam. ${ }^{14}$ In Odisha, the species was recorded from Mayurbhanj district $^{15}$ and Kalrapat Wildlife Sanctuary, southern Odisha. ${ }^{16}$

\section{Conclusion}

Indian grey hornbill (Ocyceros birostris) and Rufous woodpecker (Micropternus brachyurus) were observed at Nandankanan Wildlife Sanctuary between March and May, 2018. These species were not report earlier from the sanctuary. There is a need for further study on the bird diversity of Nandankanan in general and biology of the above species in particular to enrich our knowledge and contribute towards their conservation. 
Table I Spatiotemporal details of sighting of Indian grey hornbill and rufous woodpecker

\begin{tabular}{llllll}
\hline SNo & Species & Date & Time & Latitude & Longitude \\
\hline I & Indian grey hornbill & $25-03-2018$ & $04: 03 \mathrm{pm}$ & $20^{\circ} 23^{\prime} 43.99^{\prime \prime} \mathrm{N}$ & $85^{\circ} 49^{\prime} 17.799^{\prime \prime} \mathrm{E}$ \\
2 & Indian grey hornbill & $28-04-2018$ & $07: 48 \mathrm{am}$ & $20^{\circ} 23^{\prime} 44.1 \mathrm{I}^{\prime \prime} \mathrm{N}$ & $85^{\circ} 49^{\prime} 21.58^{\prime \prime} \mathrm{E}$ \\
3 & Rufous woodpecker & 22.05 .2018 & $07: 3 \mathrm{lam}$ & $20^{\circ} 24^{\prime} 24.3^{\prime \prime} \mathrm{N}$ & $85^{\circ} 49^{\prime} 12.9^{\prime \prime} \mathrm{E}$ \\
4 & Rufous woodpecker & 27.05 .2018 & $08: 05 \mathrm{am}$ & $20^{\circ} 24^{\prime} 20.5^{\prime \prime} \mathrm{N}$ & $85^{\circ} 49^{\prime} 10.8^{\prime \prime} \mathrm{E}$ \\
\hline
\end{tabular}

\section{Acknowledgements}

None.

\section{Conflict of interest}

Author declares that there is no conflict of interest.

\section{References}

1. Panda P, Panda S. Floral Diversity of Nandankanan Wildlife Sanctuary. Odisha: Nandankanan Biological Park, Forest and Environment Department, Government of Odisha; 2012. p. 378.

2. Kamal S, Indresh GN, Mishra AK, Vertebrate faunal diversity of Kanjia Lake, Nandankanan. e-planet. 2009;7(2):29-33.

3. Panda S, Mishra S, Mishra AK, et al. Nandankanan Faunal Diversity. Odisha: Nandankanan Biological Park, Forest and Environment Department, Government of Odisha; 2010. p. 152.

4. Mohapatra RK, Panda S, Purohit KL. Wintering avian population of Nandankanan wildlife sanctuary, Odisha. Tigerpaper XL. 2013;(2):31-34.

5. Kazmierczak K. A field guide to the birds of the Indian Subcontinent. London: Bloomsbury publishing; 2015. p. 352.

6. Naik S, Mishra AK. Photographic field guide to Birds of Sundargarh Forest Division. Odisha: Forest and Environment Department, Government of Odisha; 2017; p. 196.

7. BirdLife International. Ocyceros birostris. The IUCN Red List of Threatened Species. 2016.
8. Palei H, Debata S, Mohapatra PP, et al. Diversity and status of birds in Bonai Forest Division, Odisha, India. e-planet. 2017;15(2):166-177.

9. Mohanta R, Behera SK. An annotated preliminary checklist of birds diversity in coastal ecotourism area of Ganjam, Southern Odisha, India. Open Journal of Ocean and Coastal Sciences. 2014;1(1):83-89.

10. Debata S, Rout SD, Sahu HK. Birds of balipadar- bhetnoi community conserved blackbuck habitat, Ganjam, Odisha, India. Indian Forester. 2014;140(10):965-969.

11. Palei NC, Rath BP, Sajan SK, et al. Avifauna of Athgarh Forest Division, Odisha, Eastern India. Journal of Entomology and Zoology Studies. 2014;2(5):329-334.

12. Raja Reddy G, Baskaran M, Kumara Swamy G. Avian Diversity in around the Baitarani Reserve Forest of Joda, Keonjhar District Odisha, India. Newsletter for Birdwatchers. 2013;53(5):69-76.

13. Das KS, Sahoo PD, Dash N, et al. Avifaunal diversity of Baisipalli Wildlife Sanctuary, Odisha, India. Indian Birds. 2013;8(4):90-92.

14. BirdLife International. Micropternus brachyurus. The IUCN Red List of Threatened Species. 2016.

15. Sethy J, Samal D, Sethi S, et al. Species diversity and abundance of birds in and around North Orissa University, Takatpur, Baripada, Mayurbhanj, Odisha. International Journal of Innovative Research in Science Engineering and Technology. 2015;4(2):300-311.

16. Palei HS, Mahapatra PP, Dutta, KS, et al. Avifauna of Karlapat Wildlife Sanctuary, southern Orissa. Indian Forester. 2011;137(10): 1197-1203. 